\title{
QUIZ
}

\section{QUIZ: Paciente com úlceras em braços}

Eduardo Martelli Moreira ${ }^{1}$, Claudia Maccali ${ }^{1}$, Josiane Aparecida Neidert ${ }^{1}$, Murilo Calvo Peretti ${ }^{2}$, Mauricio de Carvalho ${ }^{1}$, Vanessa Cristhine Dallolmo Ottoboni ${ }^{2}$, Maira Mitsue Mukai ${ }^{2}$.

Caso Clínico: Homem de 65 anos, diabético tipo 2, e em tratamento por hanseníase virchowiana ( $10^{a}$ cartela de rifampicina, clofazimina e dapsona) foi admitido na enfermaria da Clínica Médica por lesões ulcerativas nas faces extensoras de membros superiores. Duas semanas antes do internamento procurou atendimento médico em outro serviço por quadro de febre, inapetência e convulsões (sic), para o qual foi prescrito ceftriaxona por 5 dias. No $3^{\circ}$ dia de tratamento, surgiram lesões inicialmente pustulosas, que evoluíram para úlceras confluentes. Estas lesões localizavam-se principalmente em cotovelos, mas acometiam também antebraços e pernas. Ao exame físico, apresentava linfonodomegalia cervical anterior, madarose e fígado palpável a 1 polpa digita do rebordo costal direito. Qual o diagnóstico?
A. Farmacodermia
B. Reação hansênica tipo 1
C. Reação hansênica tipo 2
D. Fenômeno de Lucio
E. Piodermite

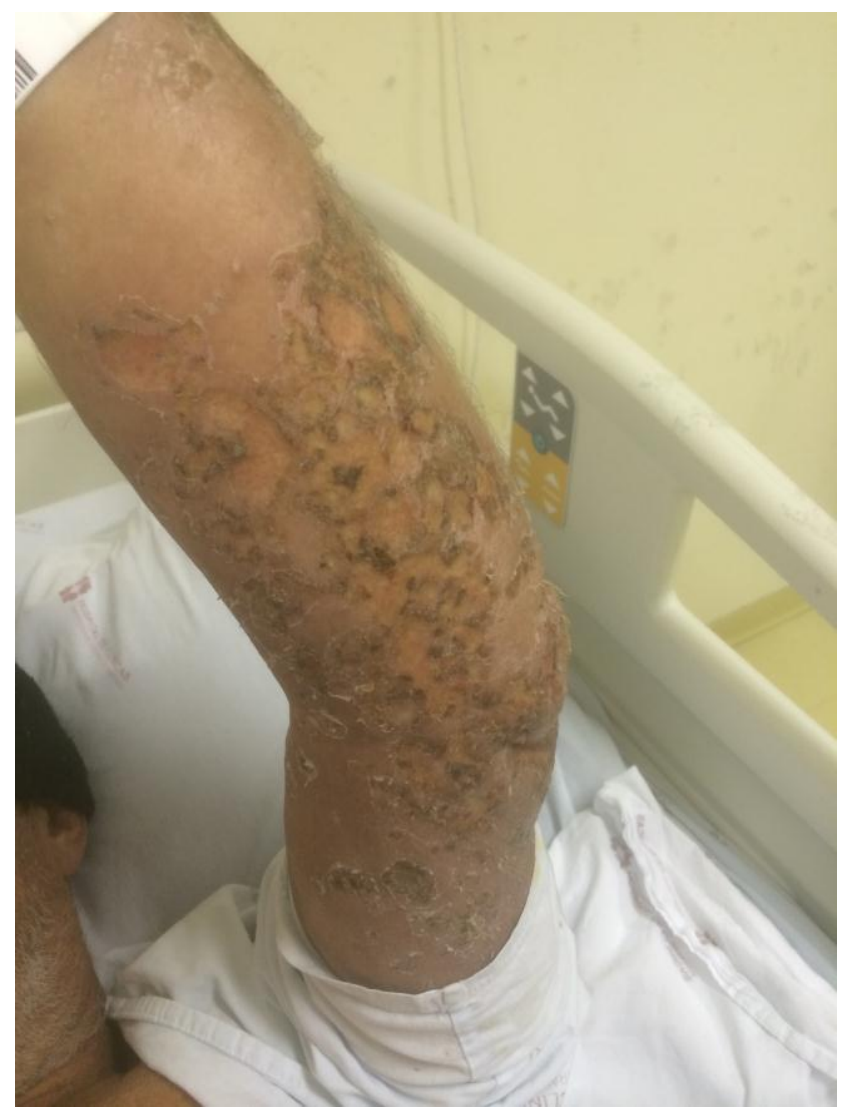




\section{REVISTA MÉDICA DA UFPR}

\section{RESPOSTA C - Reação hansênica tipo 2}

As reações hansênicas são fenômenos inflamatórios agudos ${ }^{1}$. Elas afetam em torno de 30 a $50 \%$ dos pacientes multibacilares $^{2}$. São consideradas emergências médicas, devido ao grave dano neuronal e subsequente perda de sensibilidade, paralisia e deformidade ${ }^{2}$. Elas podem ser desencadeadas por fatores como estresse, trauma físico ou psicológico, contraceptivos orais e outras drogas, além de infecções ${ }^{1}$. Existem dois principais tipos de reações, a tipo 1 (ou reação reversa), e a tipo 2 (ou eritema nodoso lepromatoso).

A reação tipo 1 é caracterizada por edema e eritema de manchas da pele, sendo sua ocorrência maior nas formas dimorfas de hanseníase ${ }^{1,2}$. As lesões cutâneas preexistentes tornam-se intumescidas, edematosas e infiltradas ${ }^{1}$. São mais frequentemente acometidos os nervos ulnar, mediano, fibular comum, facial e tibial, causando pé e mão caídos, paralisia facial e lagoftalmo ${ }^{3}$.

Na reação tipo 2 (ou eritema nodoso hansênico) surgem nódulos eritematosos dolorosos, principalmente em face extensora das extremidades superiores e inferiores ${ }^{2,3}$. Pode ocorrer em qualquer momento da doença, mas ocorre mais frequentemente durante o 1 ano de poliquimioterapia ${ }^{3,4}$. As formas graves estão associadas a febre alta, neurite, ulceração e acometimento de outros órgãos ${ }^{2}$. Ao laboratório, podem ser observados leucocitose, neutrofilia, trombocitose aumento de proteínas inflamatórias e de IgG e de IgM, além de proteinúria ${ }^{1}$.

Uma terceira intercorrência da hanseníase é o fenômeno de Lucio, que consiste de máculas avermelhadas que progridem a bolhas e necrose, e, enfim, a cicatrização atrófica ${ }^{3,5}$. É uma vasculite necrotizante que ocorre mais frequentemente na América Central, principalmente no México ${ }^{3}$. Quando ocorre superinfecção e sepse, ele pode ser fatal $\left.\right|^{3}$.

O tratamento das reações é feito a base corticóides, sem a necessidade de interrupção da poliquimioterapia ${ }^{2}$. As reações tipo 1 são tratadas por 3 a 6 meses, enquanto que o tratamento das reações tipo 2 dura cerca de 3 meses, em associação a talidomida ${ }^{1,2}$.

\section{REFERÊNCIAS BIBLIOGRÁFICAS}

1. Foss N, Souza C, Goulart I, Gonçavels H and Virmond M. Hanseníase: Episódios Reacionais. 2003.

2. World Health O. WHO Expert Committee on Leprosy. World Health Organization technical report series. 2012:1-61, $1 \mathrm{p}$ following 61.

3. Kamath S, Vaccaro SA, Rea TH and Ochoa MT. Recognizing and managing the immunologic reactions in leprosy. $J$ Am Acad Dermatol. 2014;71:795-803.

4. Voorend CG and Post EB. A systematic review on the epidemiological data of erythema nodosum leprosum, a type 2 leprosy reaction. PLoS Negl Trop Dis. 2013; 7:e2440.

5. Eichelmann K, Gonzalez Gonzalez SE, Salas-Alanis JC and Ocampo-Candiani J. Leprosy. An update: definition, pathogenesis, classification, diagnosis, and treatment. Actas Dermosifiliogr. 2013;104:554-63. 